been appointed by the Council to fill the vacancy until the next annual general meeting. The programme of lectures, discussions and meetings of the Society for the reading of papers, arranged for the session 1939-1940, will inevitably suffer drastic alterations. The Council hopes, however, that modified programmes will bo carried out, and particulars of meetings will bo announced from timo to time. Until further notice the Society's Library will bo open each weekday from 10 a.m. to 1 p.m., and from 2 p.m. to 5 p.m. or sunset when earlier, except on Saturdays, when the hours will be from 10 a.m. to 1 p.m. The Research Fund Committee will meet early in November to consider applications for grants for research purposes. These must bo received by November 1.

\section{Physical Society}

A special meeting of the Council of the Physical Society was held on Friday, September 22, to discuss the Society's activities in the immediate future. It was decided that the science meetings, the annual exhibition of scientific instruments and apparatus and the annual competition in craftsmanship and draughtsmanship should be suspended for the present, but that the publication of the Proceedings should be continued as usual. Volumo 6 of the Society's annual "Reports on Progress in Physics" is now in the printers' hands, and it is hoped that this volume will be issued at the usual time-the end of the present year. The Council recently had under consideration a project to hold local meetings of the members of the teaching and research staffs of the physics and related departments of a number of the provincial universities and university colleges; normally two such meetings would have been held in each session in the physics departments of two of the universities concerned. The officers and Council lope that, even though this scheme may not be carried out in its entirety, it may still be possible for local groups to hold meetings of an informal type under the auspices of the Society. For the present, the business of the Society will be carried on at its office at 1 Lowther Gardens, Exhibition Road, London, S.IV.7 (Telephone: Kensington 0048); all cornmunications and the MISS. of papers submitted for publication by the Society should be sent to the honorary secretaries at that address.

\section{Institution of Civil Engineers}

It is announced that the Council of the Institution of Civil Engineers has decided to continue, so far as may be practicable, the work of the Institution from the headquarters building in Great George Street, Westminster, S.W.1. The meetings of the Institution in London will be suspended until further notice, and the Conference on Engineering Education and Training and the Road Engineering Exhibition are postponed indefinitely. The October examinations of the Institution will be held in London, but not in the provinces. The Council will continue to co-operate in the work of the Central Register of the
Ministry of Labour and to assist the War Office and other Service Departments in the recruitment of qualified civil engineers for posts in which their professional experience is of value.

\section{Royal Institution}

Trif policy to be followed by the Royal Institution during the War has been under consideration by the managers, who have decided to maintain its normal activities so far as possible. The libraries and reading rooms will be kept open as usual. Although the present 'black-out' restrictions prohibit the holding of the Friday evening meetings, a series of afternoon lectures at an earlier hour is being a ranged and will he announced in due course.

\section{Royal Society}

THE: Royal Society will function normally during the war; the administrative office is located in Trinity College, Cambridge, and it is probable that the meetings of the Society will be held in that town.

\section{Institution of Professional Civil Servants}

Tre Institution of Professional Civil Servants has temporary headquarters at 20 Cedar Road, Sutton, Surrey, to which communications should be sent.

\section{Announcements}

Mre. W. C. Wruson, director of the unit for Clinical Research in Surgery at Edinburgh Royal Infirmary, has been appointed regius professor of surgery in the University of Edinburgh.

Prof. Kwanichir Terazawa, dean of the Faculty of Science of Tokyo Imperial University, has succeeded Prof. Mishio Ishimoto as director of the Earthquake Research Institute. Prof. Ishimoto will continue his researches as a member of the Institute.

Dr. Gerald B. WebB, research director of the Colorado Foundation for Research in 'Tuberculosis, has recently been awarded the Trudeau MIedal of the National Tuberculosis Association in recognition of his attempts to produce specific immunity against tuberculosis by the inoculation of animals with very minute doses of tubercle bacilli.

Consequest upon the outbreak of war, the celebration of the Royal Microscopical Society's centenary this month is postponed, and a further notification will be issued in due course.

IT was announced in NATuRE of September 30, p. 592, that the Imperial College is preparing to re-open most of its departments at South Kensington on October 10. We are asked to state that the date is not yet fixed and that students will be advised when to return. 